\title{
Denomination of origin 'Café del Huila' and dynamics of coffee growing in Colombia
}

\author{
Heiber Andres Trujillo ${ }^{(D)}$, Francisco José Mitidieri² ${ }^{\text {DD }}$, Elizabeth Mie Hashimoto ${ }^{3}$ (D)
}

\author{
${ }^{1}$ Universidade de São Paulo/USP, Escola Superior de Agricultura Luiz de Queiroz/ESALQ, Departamento de Produção Vegetal, Piracicaba, SP, Brasil \\ ${ }^{2}$ Ministério da Agricultura, Pecuária e Abastecimento, Piracicaba, SP, Brasil \\ ${ }^{3}$ Universidade Tecnológica Federal do Paraná/UTFPR, Departamento Acadêmico de Matemática, Londrina, PR, Brasil \\ Corresponding author: hatrujillos@usp.br, francisco62mitidieri@gmail.com, ehashimoto@utfpr.edu.br \\ Received in October 14, 2020 and approved in January 22, 2021
}

\begin{abstract}
The state of Huila in Colombia has a Geographical Indication -IG through the denomination of origin - DO 'Café del Huila'. Although these protection strategies have been promoted, no concrete studies have been reported on aspects of their implementation in the coffee agribusiness. The main goal of this research was to study the coffee with the denomination of origin 'Café del Huila' from 2010 to the present, through economic and performance indicators, seeking to identify the main impacts in this sector of agriculture. The research was carried out in two stages: In stage I - an analysis of the area indicators and coffee production in Colombia and an analysis of the performance of coffee growing in the state of Huila related to; municipalities, producers, farms and area. In stage II - the characterization of the denomination of origin was carried out in accordance with the methodology proposed by Food and Agriculture Organization of the United Nations - FAO (2018) and analysis of its implementation. The coffee agribusiness in Colombia showed variable dynamics in the different regions of the country, with a tendency to decrease the planted area and variability of production. The state of Huila showed significant growth both in the area planted and in production, which place it as one of the main coffee producers in the country. However, this sector presents few indicators of impact on the implementation of the geographical indication through the appellation of origin.
\end{abstract}

Key words: Intellectual property; Agribusiness; Distinctive characteristic; Coffee quality.

\section{INTRODUCTION}

Geographical indications [GI] are recognized as Intellectual Property Rights [IPRs]. They have legal existence in the world market through the 1994 Agreement on TradeRelated Aspects of Intellectual Property Rights [TRIPS] of the World Trade Organization [WTO]. Geographical indications refer to products with specific characteristics, qualities or reputations that result from their geographical origin. Within these, the Denomination of Origin [DO] is defined as "the geographical name of a country, region or locality, which serves to designate a product, originated in it, whose quality and characteristics are exclusively due to the geographical environment, including human (local knowledge and traditions) and natural factors (climate and soil) (WIPO, 1958) (Barjolle; Quiñones-Ruiz; Bagal, 2017).

Colombia has more than 140 GIs by appellation of origin, which include 16 agricultural products, including coffee, some species of flowers and some fruits (Vandecandelaere et al., 2009; Superintendencia de Industria y Comercio - SIC, 2018). In the state of Huila, since 2013, it was implemented the appellation of origin of 'Café del Huila', given the characteristics that represent the product of this region. This designation protects arabic washed coffee. This coffee is produced and processed in the state of Huila, according to the Industry and Commerce Superintendence [SIC] since 2013.

An analysis of the dynamics and performance of agribusiness through the implementation of geographical indications, represents a useful tool in understanding the impacts of these protection measures as promoters of development (Vandecandelaere et al., 2009; FAO, 2018). However, no studies have been reported that allow evaluating the performance of the agribusiness of coffee with designation of origin in Colombia, it can only be found general information.

The main goal of this research was to study the coffee agribusiness with the denomination of origin 'Café del Huila' from 2010 to the present, through economic and performance indicators, seeking to identify the main impacts of geographical indication in this sector of agriculture.

\section{MATERIAL AND METHODS}

The research was carried out using data from the historical series for the years 2010 to 2019 obtained from official institutions related to the production and marketing of coffee in Colombia (National Federation of Coffee Growers of Colombia [FNC], Information and communication network of the Colombian agricultural [AGRONET], International Coffee Organization [OIC], Ministry of Commerce, Industry and Tourism [MINCIT]. The research was carried out in two stages:

Stage I - a descriptive analysis (scatter plots) of the national production indicators (agricultural area and coffee production by state) was carried out, seeking to establish the participation of the Huila coffee industry. To describe the behavior of the states in relation to the observed variables, 
descriptive statistics were performed (summary measures for each variable and box-plot for each variable).

To study the behavior of the state of Huila in relation to the performance variables (area, municipalities, producers and farms), an principal component analysis was carried out. First, the correlation between the performance variables was carried out, according to Mingoti (2005). Next, the sphericity test $\mathrm{H}_{0}$ : $\mathrm{R}=\mathrm{I}$ versus $\mathrm{H}_{1}: \mathrm{R} \neq \mathrm{I}$, was performed, where $R$ is the correlation matrix and $I$ is the identity matrix. The test statistic was given by $\chi^{2}=-\left[(\mathrm{n}-1)-\frac{2 \mathrm{p}+5}{6}\right]$ with $\mathrm{v}=\frac{\mathrm{p}(\mathrm{p}-1)}{2}$ degrees of freedom. To select the number of principal components, it was taken into account; a) Kaiser criterion: auto values greater than 1 and b) cumulative percentage of explained variance between 80 and $90 \%$.

Stage II - the characterization of the denomination of origin was carried out in accordance with the FAO (2018) methodology of exploratory analysis and case study, using as a basis the regulations in force in Colombia by Resolution 17989 of 2013 of the Superintendency of Industry and Commerce [SIC], applied to the Huila coffee.

The year 2014 was taken as a reference (One year after the implementation of the denomination of origin 'Café del Huila'). Although this study does not correspond to a direct correlation analysis between geographical indications with the other states, 2014 represents a comparison of the Huila coffee agribusiness with the national panorama (before and after). Statistical analysis was performed with $\mathrm{R}$ software ( $\mathrm{R}$ Core Team, 2018).

\section{RESULTS}

To study the effect of the designation of origin in relation to the area planted with coffee in Colombia, Figure 1 shows the scatter plot with regression lines during the period $2010-2019$ and the red solid line represents the year of the IG Café del Huila. For these variables we can observe that the states of Antioquia, Bolívar, Caldas, Cauca, Cundinamarca, Norte de Santander, Putumayo, Quindío, Risaralda, Santander and Valle del Cauca maintained the trend of the planted area in relation to 2014, that is, they maintained the trend of growth and decrease. The other states presented changes in relation to 2014. In states with a small representation of coffee growing, such as the case of Chocó, the average and mode in the area planted with coffee was higher before 2014. However, it had decreased before this year. Later, it showed a possible increase in the area planted. The states of Boyacá and Guajira had a smaller area planted after 2014. The state of Magdalena presents a contradiction between the mean (decrease) and the median (increase) in the planted area, possibly due to the greater variability. Meanwhile, the states of Caquetá, Casanare, Cesar, Huila, Meta, Tolima and Nariño showed an increase in the area planted until 2014. However, after this period, they showed a decrease. Figure 2 presents the dynamics of coffee production by states in Colombia. According to the illustrated trend, between 2010 and 2018 the states of Cauca, Chocó, Meta, Nariño, Norte de Santander, Putumayo, Santander and Valle del Cauca did not show any change in relation to 2014. It means they maintained the growth trend, except the state of Valle del Cauca, which presented a decrease in coffee production. For Cundinamarca, both the mean and the median showed that production was slightly higher before 2014. However, during the evaluated period, the state showed a decrease and since 2014 a possible increase in production. In Antioquia and Caquetá an increase in production was observed after 2014. In Cesár and Guajira they showed a slight increase in participation until 2014 and after that year, we observed a decrease. There was a contradiction between the average and the median in the case of Risaralda, Magdalena and Casanare.

Figure 3 (left) shows that on median each state has 22 municipalities (interquartile range of 30.75), 13,092 producers (interquartile range of 30,617.25), 14,558 farms (interquartile range of $38,000.75$ ) and total area by state of 23,328 hectares (interquartile range of 48,087.25). There are possible discrepant values for Antioquia with 94 municipalities, 79,258 producers and 101,520 farms, Cauca with 90,409 producers and 114,112 farms and Huila with 82,761 producers, 100,520 farms and 144, 896 planted hectares. Figure 3 (lower right) shows the correlations between the variables and in the upper part the intensity of these correlations. It is observed that the variables producers, farms and total area presented a very strong positive correlation. The variable municipality had a moderate positive correlation with the other performance variables. As there was a correlation (sphericity test with $p$-value $<0.0001$ ) between the performance variables, the principal component analysis was performed.

Through the principal components analysis, the variation showed that only the first component had a self-value greater than 1. Therefore, the first two components explain more than $90 \%$ of the total variability of the performance parameters of coffee production in the country. In the first principal component $(\mathrm{CP} 1)$, the variables farms $(0.53)$ and production area (0.52) stand out. In the second principal component (CP2), the variable municipality stands out $(0.91)$. In Figure 4 , the variables of producers / states, farms / state and area / state present a greater contribution for the first principal component, since this is close to CP1 (principal component 1) (13\%), regarding the variable municipalities, is closer to $\mathrm{CP} 2$ (principal component 2) (85\%). States that are closer together indicate greater similarity. For instance, this is the case of the states of Cauca and Huila. Extending the producing vectors, farms and area, we have that Antioquia, Huila, Cauca and Tolima are the states with the best performance for these variables. Followed by the states of Caldas, Nariño, Santander, Cundinamarca and Valle. Extending the vector municipalities, Antioquia, 
State
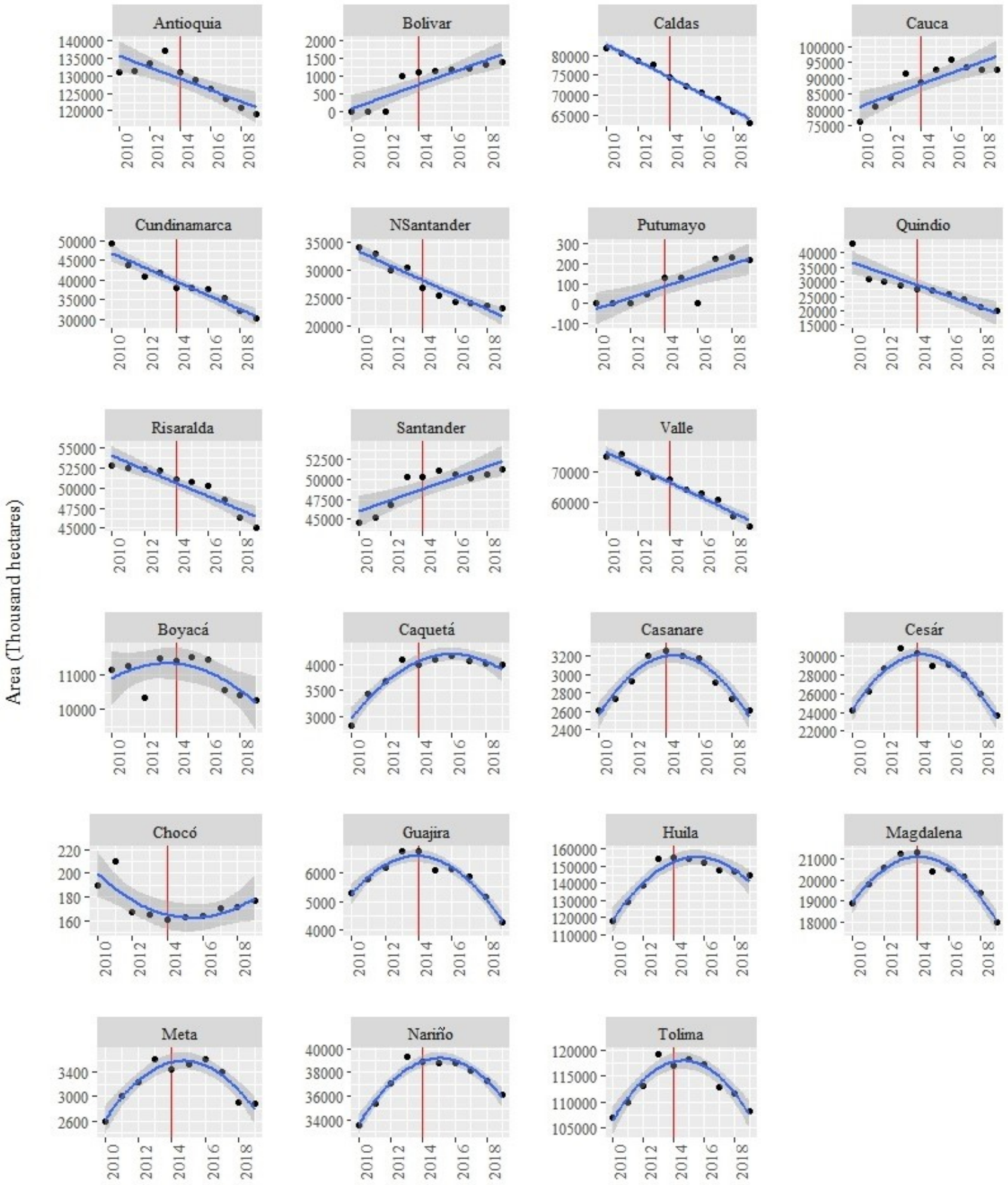

Year

Figure 1: Dispersion of area planted with coffee (One thousand hectares) versus year with linear and quadratic trend of each of the states in Colombia from 2010 to 2019. Prepared authors, data (Federación Nacional de Cafeteros de Colombia - FNC, 2020). 

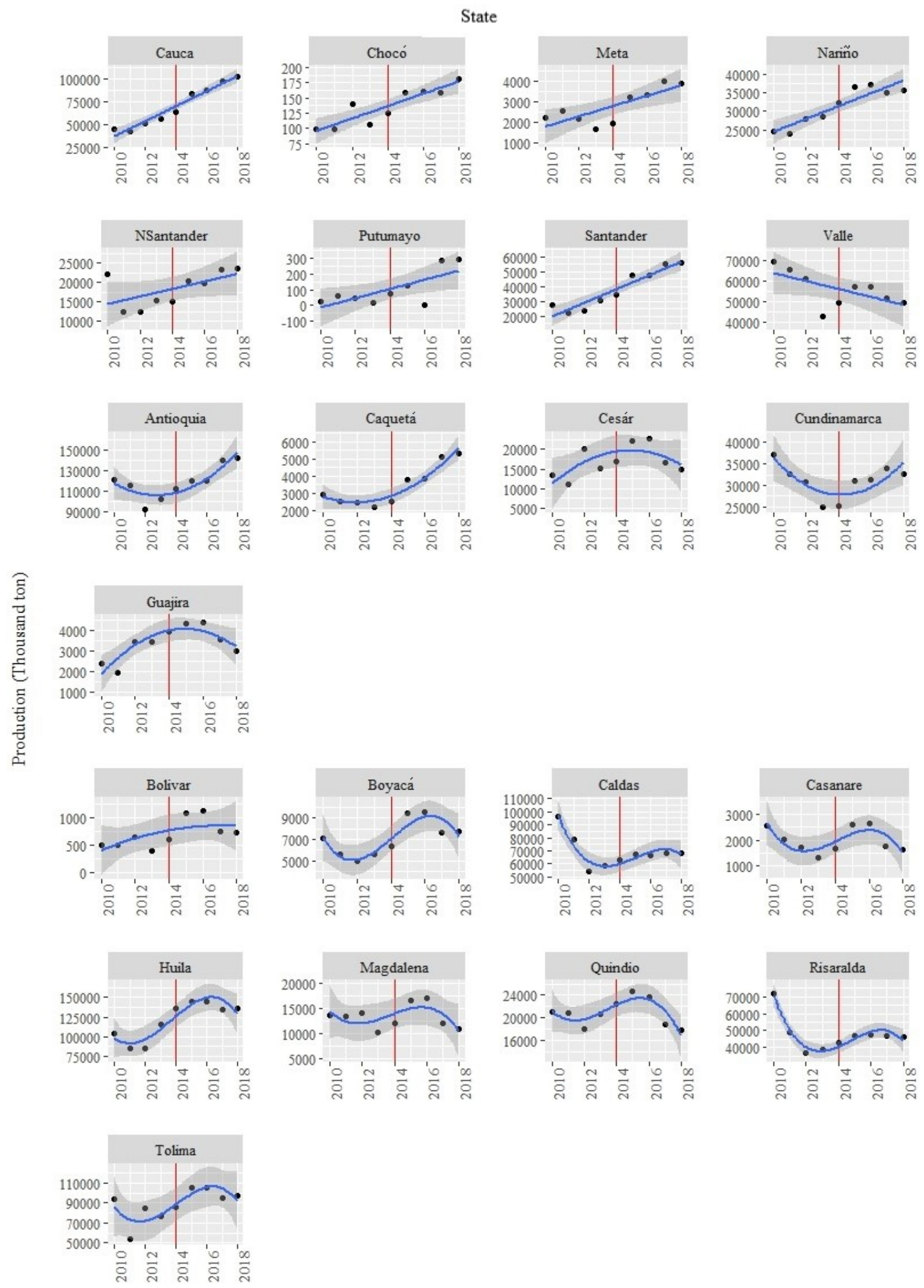

Year

Figure 2: Dispersion of coffee production (Thousand Tons) versus year with linear, quadratic and cubic trend of each of the states in Colombia from 2010 to 2018. Prepared authors, data AGRONET (2019). 
Santander and Cundinamarca are the states with the largest number of coffee producing municipalities. Next are Huila, Cauca, Tolima, Nariño, Valle, Norte de Santander and Boyacá. Although Santander and Boyacá have a considerable number of municipalities, they have fewer producers, farms and planted area. In the upper left box (Figure 4), we have the states with the least number of municipalities, producers, farms and area, as they are on the opposite side of the performance variables. For the grouping of the states according to the performance variables analyzed here, we can observe that the states of Antioquia, Huila, Tolima, Cauca are similar in their performance. It is important to highlight that, although in the Amazon region (states of Caquetá and Putumayo) there is development of coffee activity, this is small compared to the other regions.
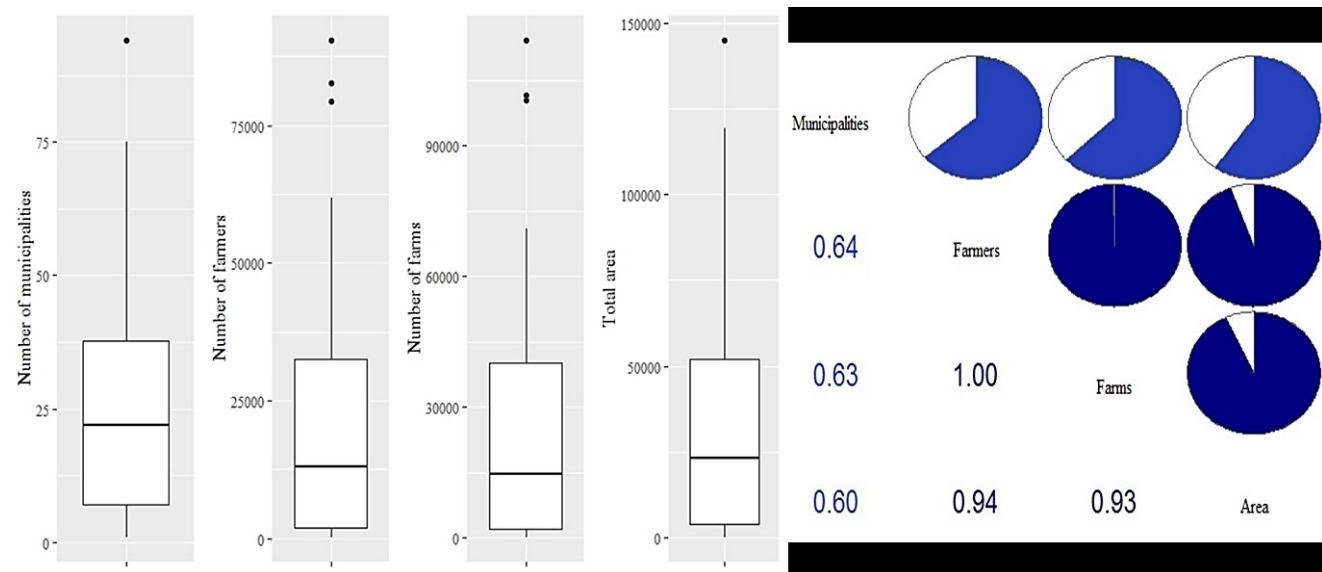

Figure 3: Box-plot (left) and correlogram (right) of the performance variables; municipalities, producers, farms and areas in the coffee producing states in Colombia from 2010 to 2019.

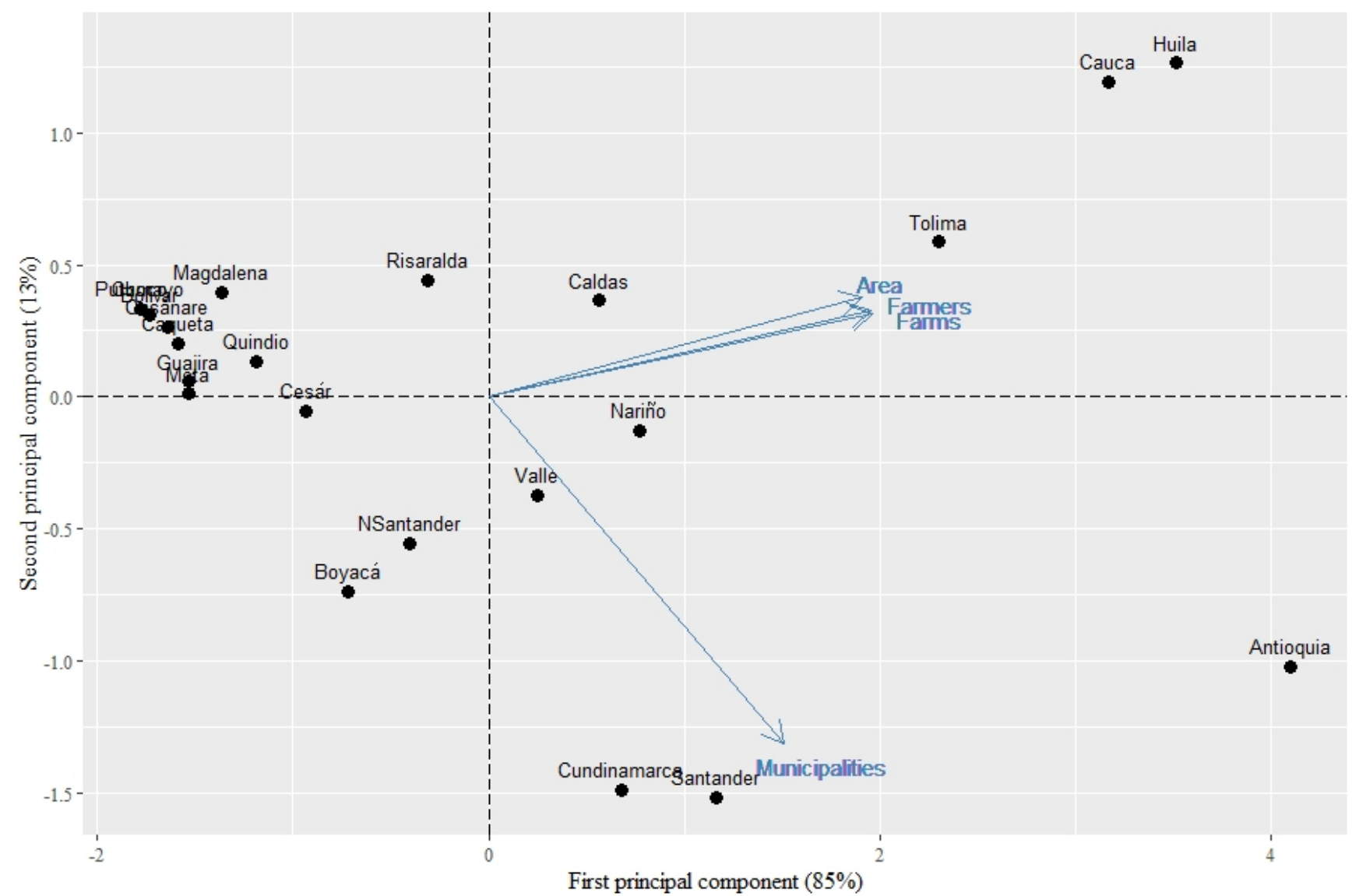

Figure 4: Biplot of performance variables (municipalities, producers, farms and area) for each of the coffee producing states in Colombia from 2010 to 2019. 
Table 1 shows the characteristics of the coffee produced in the state of Huila, described by the resolution of denomination of origin 'café del Huila' issued by the Superintendency of Industry and Commerce [SIC], through Resolution 17989 of 2013. This resolution establishes the parameters that the product must comply with to be considered within the norm and therefore make use of its name and its benefits in the national territory. The data are proportional to the parameters used by FAO (2018) and adapted to the product object of this study, that is, for the coffee from Huila. This includes cultivation, harvesting, processing, drying until parchment, threshing and classification. The geographical location of the state of Huila in the Colombian territory, which for the purposes of the denomination of origin 'Café del Huila' (SIC, 2013), corresponds to the geographical area delimited in an altitude range between 1000 to 2200 meters above sea level, precipitation normal between 1300 to 1640 millimeters per year, relative humidity between 75 to $83 \%$ and sunlight between 1200 to 1250 hours of light per year. Out of the 37 municipalities in the state, 35 have coffee growing as their main agricultural activity, including the municipalities of Acevedo, Agrado, Aipe, Algeciras, Altamira, Baraya, Campoalegre, Colombia, Elias, Garzón, Gigante, Guadalupe, Hobo, Iquira, Isnos, Argentina, La plata, Nátaga, Neiva, Oporapa, Paicol, Palermo, Palestina, Pital, Pitalito, Rivera, Saladoblanco, San Agustin, Santa Maria, Suaza, Tarqui, Tello, Teruel, Tesalia and Timaná.

Regarding the states' exports, Figure 5 presents the export volume and the estimated value of the annual harvest of the Huila state, with respect to the volume and value of the national harvest. An exponential increase was observed from 2012 to 2017 . These increases in the volume of exported coffee have a proportional relationship with the rise in the growing area in the same period (Figure 1), associated with higher coffee production in all regions of the country (Figure 2). No data was available for 2018 and 2019.

\section{DISCUSSION}

According to the FNC (2020), the significant reduction in the area planted in Colombia (Figure 1), which went from 914,412 ha in 2010 to 853,700 ha in 2019 is mainly due to the decision of coffee growers to abandon this agricultural activity. Mainly because of the low prices on the product that do not cover production costs. Therefore, it was not possible to identify a trend during the period with respect to the production before and after 2014 (Figure 2). In the other states, including the state of Huila, it was not possible to observe a trend, since production seems to decrease and increase over time. Along with the reduction in the national area, mainly in 2011 and 2012 (Figure 1), production by state presented similar variations throughout the period. In 2010, a national production of 8,923,000 bags was reported (60 kg bags of equivalent green coffee: Coffee in the form of beans without coverage before roasting) and 13,557,000 bags for 2018. However, Colombia reached more than $14,000,000$ bags for the year 2019, according FNC (2020). Between 2017 and 2018, world coffee production was 158.1 and 170.9 million bags respectively (International Coffee Organization - ICO, 2020), which meant a $3.6 \%$ recovery with respect to the drop in production in previous years. This increase in world production was a consequence of the increase in production in Brazil, which was in its high two-year period, in addition to the good weather conditions that favored production in Vietnam. Production data by state for 2019 was not reported (or available) during this research.

Table 1: Factors and characteristics of the denomination of origin 'Café del Huila'

\begin{tabular}{|c|c|}
\hline Factor & Characteristic \\
\hline IG product & Denomination of origin 'Café del Huila' \\
\hline Product description & $\begin{array}{l}\text { Balanced overall impression, sweet notes, acidity and medium / high body, intense fragrance / aroma with a } \\
\text { sensation of fruits and caramel }\end{array}$ \\
\hline Scope & 35 producing municipalities. Production of the determined region \\
\hline Location & $\begin{array}{c}\text { The geographical area of production of the 'Huila coffee', or the Huila Coffee region, is defined in the Resolution } \\
\text { of the declaration of protection-Denomination of Origin }\end{array}$ \\
\hline Trade & National and international. \\
\hline $\begin{array}{l}\text { Organization and } \\
\text { Producers }\end{array}$ & $\begin{array}{l}\text { Farmer segmentation, movement of dry parchment coffee, threshing record, record of coffee coming out of the } \\
\text { thresher, quality control of coffee in port, record of roasters and soluble companies in Colombia, record of exporters }\end{array}$ \\
\hline Commercial register & $\begin{array}{l}\text { Natural or legal people authorized by the FNC, to make use of the denomination, can be identified as 'Café del } \\
\text { Huila' in the manner provided } \\
\text { Coffee that meets the requirements established in the Declaration of the Protecton Resolution - Denomination of Origin }\end{array}$ \\
\hline Certification & Resolución No. 17989 del 16 de abril de 2013 de la Superintendencia de Industria y Comercio - SIC \\
\hline
\end{tabular}




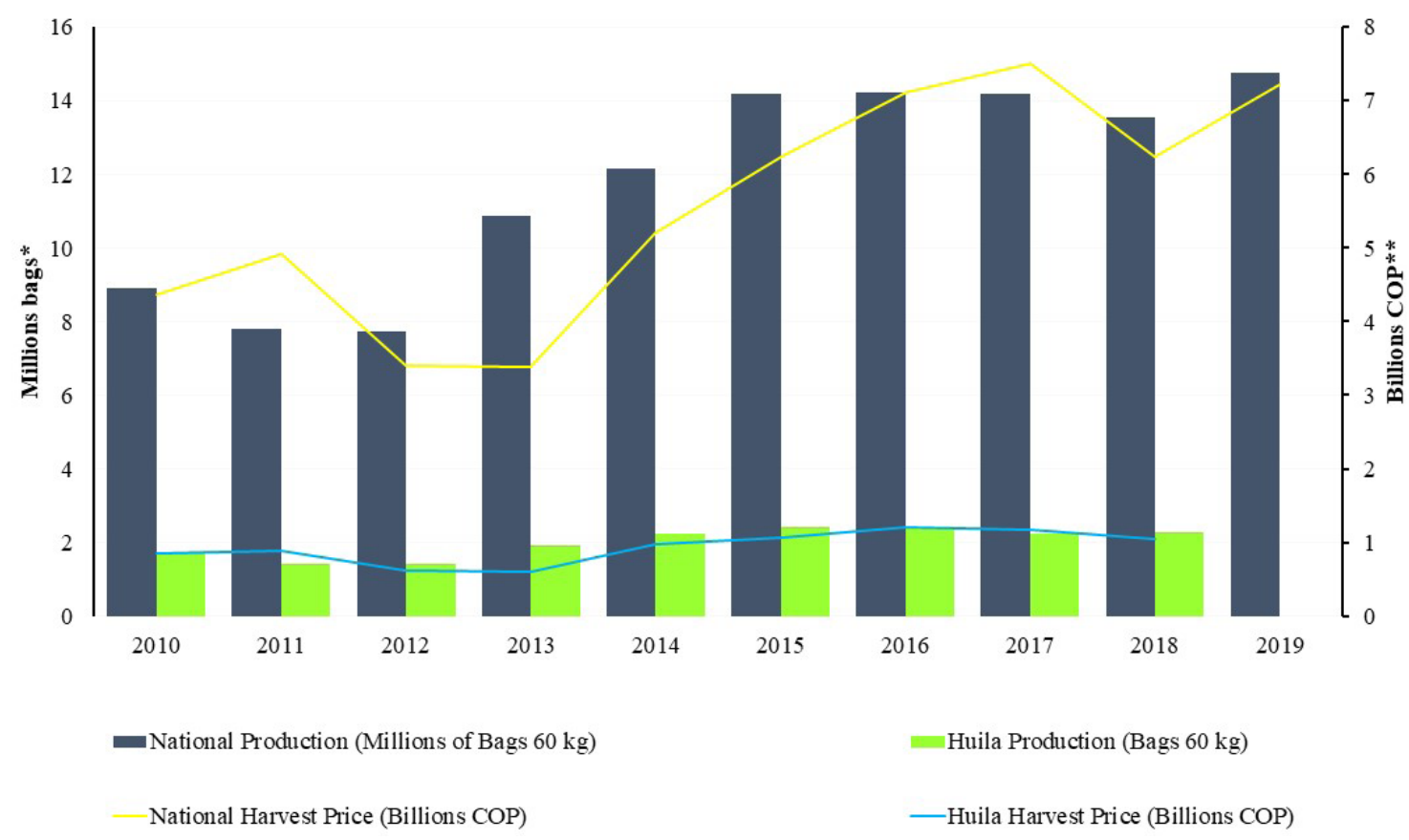

Figure 5: Fluctuation of the volume of exports (Millions of bags of $60 \mathrm{~kg}$ green coffee*) and value of the annual Huila coffee harvest (Millions of $\mathrm{COP}^{* *}$ ) compared to the volume and value of the national harvest.

Colombian coffee growing is represented by coffee crops of the arabica species (Coffea arabica), washed, distributed in the five natural regions of the country in the Andean, Caribbean, Pacific, Orinoquia regions and in a small proportion in state of the Amazon region, However, the highest percentage of coffee production in Colombia is concentrated in the Andean region (center of the country). According to Avelino et al. (2015), Colombian coffee growing throughout its development in the country has had a greater boom in this region. Furthermore, these indicators can be contrasted with the variables previously analyzed, where these states also had a greater area planted in coffee, as well as greater production. Currently, Colombian coffee farming is made up of 853,700 hectares in 22 states and 602 coffeegrowing municipalities, where the activity is carried out by small farmers (FNC, 2019). The main varieties planted are: Tipica, Borbón, Maragogipe, Tabi, Caturra and the Castillo Variety (Barrios; Salas-Calderon; Giron-Hernandez, 2020). The general characteristics of Colombian coffee are due to the wide diversity of both natural and cultural factors that each coffee region represents, which, added to the typicality and production practices, give the coffee its own qualities in every niche.

A large part of the area dedicated to coffee cultivation is represented by varieties resistant to pests and diseases, an important element that, added to production techniques and environmental factors, allow to achieve yields greater than 18.5 loads ha-1 (loads of 125 kilos) (FNC, 2019). These indicators are important to maintain productive activity in the region.

Coffee growing in the state of Huila, this is represented by arabica coffee, washed, which is grown in an approximate area of 144,900 ha, according to FNC (2020). It corresponds to the state with the largest area currently planted in Colombia (Figure 1). According to the Barjolle and Sylvander (2002), the produ $\mathrm{ct}$ has achieved quality, reputation and other characteristics that are unique or essentially attributed to the geographical environment in which it is produced, including natural a n d human factors. Therefore, it was granted the designation of origin in 2013. This type of description allows those int e rested in the agribusiness (producers, exporters, roasters and consumers) to know the parameters and minimum character i stics of the product. In states such as Antioquia, the GI im plementation process advances in verifying the environme $\mathrm{n}$ tal characteristics, quality and reputation of the product, as well as the human factor that would make their coffee wo $r$ thy of a designation of origin (Barrios; SalasCalderon; Giron-Hernandez, 2020). According to FNC (2019), despite the fact that the SIC, through the respective standard, has the year of implementation of the Denomination of Origin 'café del Huila' in 2013, it is only until 2016 that the producing and marketing companies begin to make use of this geographical indication. Although the Huila state and the Nariño state lead the numbe $r$ of companies registered to make use of their respective denominations of origin ( 8 and 7 , respectively), the national implementation for this indicator is scarce. 
According to data from AGRONET (2019), for 2018, Huila's share of the volume of national production was close to $16 \%$. With reference to the volume of production by state for 2019, no updated data were found to verify the percentage share. Regarding the value of the harvest, Figure 5 illustrates a changing dynamic during the evaluated period. During 2017 and 2018, the Colombian coffee growing, including the state of Huila, there was a reduction in income represented in the value of the state harvest. After the manufacturing industry, coffee growing is the second production activity in the state of Huila, in the regional scenario, coffee agribusiness represents $52 \%$ of the agricultural GDP and $7.8 \%$ of the total GDP of the state (Mincit, 2020). An important aspect to highlight of the activity is its participation in the generation of jobs, especially in the generation of rural employment.

Regarding the promotion in the foreign market, the FNC promotes the consumption of Colombian coffee abroad as a direct exporter of the bean. Among the types of coffee promoted are origin coffees that include Huila coffee as a type of regional coffee, as well as sustainable coffees and preparation coffees. In addition to these three categories of trade, there are certified coffees, that is, those that meet internationally defined standards by certification agencies. In the case of 'Café del Huila', the main certifying agencies are; "Fair-trade Labeling Organization, Rainforest Alliance, Utz Kapeh and Bird Friendly". Another important aspect related to the promotion of the quality of the coffee produced in the state of Huila, is the development of coffee quality competition events. In the case of the "Cup of excellence ${ }^{\circledR}$ " contest (international contest also held in Colombia) among 11 versions carried out since 2003, the state of Huila is reported as the winner of five versions $(2005,2006,2007,2011$ and 2013) (Bhumiratana; Adhikari; Chambers, 2011; Valencia; Pinzón; Gutiérrez, 2015; Barrios; Salas-Calderon; GironHernandez, 2020). In addition to participating in international events where the quality of the crops is promoted, these spaces also attract direct markets, where the buyer and seller have an exchange of experiences on commercial agreements. The denomination of origin mechanism can represent a strategy for producers through their collective organization, allowing them to modify the market organization and intervene indirectly in the price. However, by the indicators, especially those that indicate the implementation of this GI, the ignorance of this type of protection mechanisms is evident both at the base of production and in the value chain.

As Barjolle, Quiñones-Ruiz and Bagal, (2017) highlighted, coffee in Colombia has reached high quality standards, being considered one of the best in the world. According to these authors, the appellation of origin is a guarantee that coffee producers and buyers have because it provides security and confidence in their commercialization. Thus, one of the main advantages perceived with the implementation of protection measures through the appellation of origin, refers to guaranteeing a high quality product for the consumer. Therefore, producers can receive an over-price in marketing. In relation to the transfer of agribusiness profits to producers in the case of Colombian coffee, the value increased after the GI was recorded (from $68 \%$ to $85 \%$ ) for every dollar paid by roasters, according to FAO (2018). However, for the 'café del Huila', a detailed analysis that allows us to know the redistribution of additional value may be subjective with the data available here. Because it is a non-homogeneous product, the International Coffee Organization classifies the price of coffee in different groups; I - the coffees with geographical indication (Colombian arabica coffees, other mild arabica coffees, Brazilian and other Arabicas) and II Robusta coffee (Barjolle; Sylvander, 2002). This system makes it difficult to establish the specific price for each region according to its classification, a factor that creates a degree of uncertainty throughout the agribusiness chain, especially for producers. Furthermore, since coffee is a commodity, it faces the volatility of international prices, important factors when it comes to understanding the variation in the price of coffee. In the Colombian case, the National Federation of Coffee Growers of Colombia is the entity that establishes a minimum internal price paid to coffee producers. This price covers all types of coffee produced in the country, including those with denomination of origin.

The coffee agribusiness in regional and national scenarios faces weaknesses mainly related to price fluctuations in the international market and some adverse climatic factors, resulting in a less competitive system compared to other growing sectors (Avelino et al., 2015). Another obstacle faced by the Colombian coffee agribusiness has to do with its profitability. In coffee growing, profitability depends on a relationship between the income received from the sale of the harvest and the costs that were assumed for the production of it. To determine income, the price of coffee on the New York Stock Exchange, the quality premium granted for Colombian Coffee and the current exchange rate must be taken into account (Barjolle; Sylvander, 2002). The industry is currently challenging a crisis related to negative balances between production costs and activity profits. The internal price that coffee producers receive per $125 \mathrm{~kg}$ load is approximately USD 220, a price that does not cover the estimated production costs of USD 245. Even though specific figures for Huila coffee are not available, they could have the same dynamics, since prices are set for the Colombian market in general, regardless of regions.

\section{CONCLUSIONS}

The synthesis of the data indicates that coffee growing is a dynamic activity in each of the regions and involves a large 
number of variables and those responsible for its operation. Despite the reduction in coffee growing in the country, mainly due to the area planted, growth could be observed in the participation of the department of Huila in national agricultural development during the evaluated period.

The geographical indication through the denomination of origin 'Café del Huila' has in some cases allowed the recognition of this product as one of the best in the country due to its characteristics, promoting support for the coffee activity by promoting and protecting the product in local and international markets for its broad attributes and quality.

The development of coffee growing in Colombia presents great challenges related to the access to protection measures, to price fluctuations and the profitability of the activity through product differentiation. However, to establish correlations between agribusiness performance and GI implementation, additional studies with as many variables as possible are suggested.

\section{REFERENCES}

AVELINO, J. et al. The coffee rust crises in Colombia and Central America (2008-2013): Impacts, plausible causes and proposed solutions. Food Security, 7(1):303-321, 2015.

BARJOLLE, D. X. F.; SYLVANDER, B. Some factors of success for origin labelled products in agri-food supply chains in Europe: Market, internal resources and institutions. Economies et Sociétés, 10(1):1-21, 2002.

BARJOLLE, X. F.; QUIÑONES-RUIZ, M.; BAGAL, H. $\mathrm{C}$. The role of the state for geographical indications of coffee: Case studies from Colombia and Kenya. World Development, 98(1):105-119, 2017.

BARRIOS-RODRIGUEZ, Y. F.; SALAS-CALDERON, K. T.; GIRON-HERNANDEZ, J. Comparison of sensory attributes and chemical markers of the infrared spectrum between defective and non-defective Colombian coffee samples. Coffee Science, 15:e151659, 2020.

BHUMIRATANA, N.; ADHIKARI, K.; CHAMBERS, E. Evolution of sensory aroma attributes from coffee beans to brewed coffee. LWT - Food Science and Technology, 44(10):2185-2192, 2011.

FEDERACIÓN NACIONAL DE CAFETEROS DE COLOMBIA - FNC. Producción de café en Colombia. 2019. Available in: $<$ https://federaciondecafeteros.org/wp/ estadisticas-cafeteras/>. Access in: December, 01, 2019.

FEDERACIÓN NACIONAL DE CAFETEROS DE COLOMBIA - FNC. Estadísticas cafeteras. 2020.
Available in: $<$ https://federaciondecafeteros.org/wp/ estadisticas-cafeteras/>. Access in: April 20, 2020.

FOOD AND AGRICULTURE ORGANIZATION OF THE UNITED NATIONS - FAO. Strengthening sustainable food systems through geographical indications: An analysis of economic impacts. Roma, Italia, 2018. 158p.

INTERNATIONAL COFFEE ORGANIZATION - ICO. Historical data on the global coffee Trade. 2020. Available in: < http://www.ico.org/new_historical. asp?section=Statistics $>$. Access in: May, 05, 2020.

MINGOTI, S. Análise de dados através de métodos de estatística multivariada: Uma abordagem aplicada. Editora UFMG, 2005. 295p.

R CORE TEAM. R: A language and environment for statistical computing. R Foundation for Statistical Computing, Vienna, Austria. 2018. Available in: < https://www.gbif.org/pt/tool/81287/r-a-language-andenvironment-for-statistical-computing $>$. Access in: January, 08, 2021.

\section{RED DE INFORMACIÓN Y COMUNICACIÓN DEL} SECTOR AGROPECUARIO DE COLOMBIA AGRONET. Evaluaciones agropecuarias del Ministerio de Agricultura y desarrollo rural. Producción nacional por producto por producto. 2019. Available in: $<$ https://www.agronet.gov.co/estadistica/Paginas/home. aspx?cod=1>. Access in: December, 20, 2019.

\section{REPÚBLICA DE COLOMBIA - MINISTERIO DE} COMERCIO INDUSTRIA Y TURISMO - MINCIT. Información: Perfiles económicos departamentales. 2020. Available in: $<$ https://www.mincit.gov.co/estudioseconomicos/perfiles-economicos-por-departamentos $>$. Access in: May, 05, 2020.

\section{REPÚBLICA DE COLOMBIA - SUPERINTENDENCIA} DE INDUSTRIA Y COMERCIO -SIC. Productos con denominación de origen. 2018. Available in: $<$ https:// www.sic.gov.co/productos-con-denominacion-de-origen $>$. Access in: August 30, 2019.

REPÚBLICA DE COLOMBIA - SUPERINTENDENCIA DE INDUSTRIA Y COMERCIO - SIC. Resolución n. 17989 del 16 de abril. 2013. Available in: $<$ https://www.sic. gov.co/sites/default/files/files/Denominacion $\% 20 \mathrm{de} \% 20$ Origen/Agro $\% 20-\% 20$ Alimenticios/Caf\%c3\%a9\%20 del\%20Huila/cafe_de_huila.pdf $>$. Access in: December, $05,2019$.

\section{VALENCIA, J.; PINZÓN, M.; GUTIÉRREZ, R.}

Caracterización fisicoquímica y sensorial de tazas de café producidas en el departamento del Quindío. Revista Alimentos Hoy, 23(36): 150-156, 2015. 
VANDECANDELAERE, E. F. et al. Linking people, places and products. A guide for promoting quality linked to geographical origin and sustainable Geographical Indications. Rome: SINER-GI, p.2-28, 2009.
WORLD INTELLECTUAL PROPERTY ORGANIZATION WIPO. Lisbon Agreement for the protection of appellations of origin and their international registration. Lisbon, 1958. Available in: <https://www.wipo.int/lisbon/en/legal texts/ lisbon_agreement.html >. Access in: January, 08, 2020. 